\title{
THE PRESUMPTION OF INNOCENCE IN CRIMINAL CASES.*
}

In the case of Coffin $v$. United States, ${ }^{1}$ decided in March, I895, the Supreme Court of the United States had an opportunity to clear up the confusion and ambiguity that hang over the common talk about the presumption of innocence in criminal cases. The opportunity was sadly misimproved. It is quite time that the opinion in this case should be subjected to a critical examination. This is all the more desirable because the tendency of it is to encourage that feeble administration of our criminal law which is doing so much in these days to render it ineffectual.

It will be desirable, in order fully to understand the matter, to enter upon some preliminary explanations. England, our mother country, had formerly an extremely harsh body of criminal law. Fitzjames Stephen, forty years ago, declared that "the English judges of the eighteenth century administered what, without any exception, was the most cruelly severe penal code that ever existed." Blackstone tells us that, in his time there were one hundred and sixty capital offences without benefit of clergy, for " actions which men are daily liable to commit!" s

In Henry the Eighth's reign of thirty-eight years it is said that eighty thousand persons were executed in England as common malefactors. In ten years of James the First's reign, from 1609 to $16 \times 8$, inclusive, nearly fifteen hundred persons were hanged in the city of London, and in the County of Mid. dlesex alone, including the considerable number (thirty-two in Middlesex) who died by the peine forte et dure." In the sixteenth century, in treason and felony, no witness was allowed for accused persons; in the seventeenth century the witnesses that were received for them were not allowed to be sworn: and no counsel was permitted to help them in trying their case on the

* This paper contains the substance of one of the Storrs Lectures of 1896. I56 U. S. 432.

2 Jurid. Soc. Papers, i. 468.

S Com., IV. I8.

Jeaffreson's Middlesex County Records, Vol. 2, xvi-xxi. 
facts, until in the eighteenth century, "by the connivance of the court," and, finally, by statute, in r834. The judges were removable by the Crown until the .English Revolution, and notwithstanding the maxim that they were to act as counsel for the accused, they were greatly in the habit of considering everything favorably to the Crown. Torture was practiced in some cases. It may be remarked, in passing, that torture was recognized even in New England in the seventeenth century. In the colonial laws of Massachusetts we read: "No man shall be forced by torture to confess any crime against himself or any other, unless it be in some capital case, where he is first fully convicted by clear and sufficient evidence to be guilty; after which if the case be of that nature that it is very apparent there be other conspirators or confederates with him, then he may be tortured, yet not with such tortures as are barbarous or inhumane." "s

But all this cruelty was accompanied and relieved by humane maxims, rules of procedure, and practical adjustments of one sort and another, which tended to make it endurable. ${ }^{6}$ There was the jury system, which protected accused persons through the sympathies of their fellow-citizens. There was the common law system of evidence which saved them, in an increasing degree, from being tried on prejudice. There was the maxim, running back into the earliest Year Books, that no person should be twice put in jeopardy of life or limb. And there was the principle that it were better that a guilty person should be un-

- Laws of I660 (Whitmore's Edition), I87; Anc. Charters and Laws of Mass., 180. The year of this enactment is not given. What is called "The Laws of $1660, "$ is a compilation of that year.

- It may be added that our administration of the criminal law to-day, in a period when the substantive law is merciful, is sadly enfeebled by a continuance of some rules and practices which should have disappeared with the cruel laws that they were designed to mitigate. I may refer to the refusal of new trials to the government in some classes of cases, to the absurd extreme to which the rule about confessions in evidence is sometimes pressed, to the strained interpretation of the prohibition of ex post facto laws, to the continuation of technicalities of criminal procedure and practice which have lost their reason for existence and to a superstitious rigor in enforcing these, which still shows itself. In following English precedents in such matters, we forget to sup. plement them by that saving good sense which appears in the swiftness and vigor of the English administration of criminal law. If we follow English practices we should remember that they are all meant to go together. Excellent criticisms of this sort may be found in the dissenting opinion of Peckham, J., speaking for himself and Justices Brewer and White, in Crain $v$. U. S., I62 U. S. 625, 646, 650. He justly characterizes the result arrived at in the opinion of the court as " most deplorable." 
punished than that an innocent one should be condemned-a doctrine laid down in the Digest, "where it is attributed to the Emperor Trajan.

That maxim, by the way, has had a singular history. First found in the Digest, it appears in the Year Books of Edward the First, twelve centuries later, in substantially the same form above quoted. ${ }^{8}$ In the fifteenth century we find Fortescue saying: "Truly I would rather that twenty guilty men should escape through pity than that one just man should be unjustly condemned." "Two centuries later we have Sir Matthew Hale saying that "It is better that five guilty persons should escape unpunished than that one innocent person should die."10 A little later we find one of the victims of Titus Oates's perjury saying to the judges with pardonable exaggeration that, "It is better a thousand guilty men should escape than one innocent man should die." A A century later Blackstone tells us that, "It is better that ten guilty persons should escape than that one innocent person should suffer." 12 Early in the present century, in a series of Irish cases, we find it repeatedly said that "It is better that ninety-nine guilty persons should escape than that one innocent man should be punished." trial of Dr. Webster, in $18{ }_{5},{ }^{14}$ Professor Joel Parker, formerly Chief-Justice of New Hampshire, is found, as Paley before him, and Fitzjames Stephen since, stoutly controverting the statement of Blackstone, that ten guilty persons should escape rather than one innocent person suffer; but prepared to admit that it is better that one should escape than that an innocent person should suffer. And thus we may return to the moderation of the early proposition in the corpus juris. Obviously these phrases are not to be taken literally. They all mean the same thing, differing simply in emphasis-namely, that it is better to run risks in the way of letting the guilty go, than of convicting the innocent.

Another of those practical adjustments favorable to the accused person which enabled our English ancestors to endure the horrors of their substantive criminal law, was the doctrine of

\footnotetext{
${ }^{7} 48,19,5$.

B. B. 30 and 31 Edw. I., 538.

${ }^{9}$ De Laud. c. 27.

${ }^{10} \mathrm{P}$. C. II., 289.

11 Lord Stafford's Case, 7 How. St. Tr. I529 (I69o).

12 Com. IV., 358.

${ }^{13} E$. $g$., in Killen and McCann's Case, 28 St. Tr. 1or3 (1803).

${ }^{14} 72$ N. A. Rev. 200-202.
} 
benefit of clergy: originally the benefit in certain capital cases, if the accused were an ecclesiastic, of being turned over to the spiritual arm, and not hanged, for the ecclesiastics never hanged. The test of an ecclesiastic was that he could read, and so the Bishop sent in a representative to try the accused with his "neck verse." As Smith in the sixteenth century, in his "Commonwealth of England," tells us: "In many felonies, as in theft of oxen, sheep, money or other such things, which be no open robberies by the highway side, nor assaulting one by night in his house, putting him that is there in fear, such is the favor of our law, that for the first fault the felon shall be admitted to his clergy, for which purpose the Bishop must send one with authority under his seal to be judge in that matter at every jail delivery. If the condemned man demandeth to be admitted to his book, the judge commonly giveth him a psalter, and turneth to what place he will. The prisoner readeth so well as he can (God knoweth, sometimes very slenderly): then he [the judge] asketh of the Bishop's commissary, legit ut clericus? The commissary may say legit, or non legit; for these be words formal, and our men of law be very precise in their words formal. If he say legit, the judge proceedeth no further to sentence of death; if he say non, the judge forthwith, or the next day, proceedeth to sentence." 15 This came to be the general test in what continued to be called the benefit of clergy - the power to read, and these imaginary ecclesiastics, were discharged with little or no punishment. One who had claimed this privilege, and had it, was branded on the brawn of his thumb, so that if he appeared again he might be known; for he could have it only once.

We also had benefit of clergy, on this side of the water. It was allowed in the case of the soldiers who were convicted of manslaughter at the Boston Massacre. Benefit of clergy, in England, was abolished in $\times 827$. For centuries it mitigated, substantially, the severity of the English criminal law.

Always, of course, there was operating in favor of the accused the sound maxim of general jurisprudence that the plaintiff or, rather, the party who seeks to move the court, must make out a reason for his request. This rule is sometimes expressed in the form of a presumption, prestumitur pro neganti; or, having regard to the Latin terms for plaintiff and defendant, actor and reus,-presumitur pro reo. That is a maxim of policy and practical sense; it is not founded on any notion that defendants generally are free from blame. It is a maxim or principle that

15 Smith's Com., Eng. Bk. II. c. 27. This book was written in 1565. 
saves the defendant by the mere inertia of the court, if the plaintiff does not make out his case. This maxim, in this bare form, and without the familiar additional clause as to the greater force of persuasion in criminal cases, always operated for the accused. It is probably true that in the form last given it has sometimes been mistranslated, and given a special application to criminal cases, as if reus necessarily meant a person charged with crime, and not merely, as it truly does, a defendant in any sort of a case. The operation and exact scope of this maxim, both in civil and criminal cases, was very neatly expressed by the General Court (the Legislature) of Massachusetts so long ago as r657, as follows: "Whereas, in all civil cases depending in suit, the plaintiff affirmeth that the defendant hath done him wrong and accordingly presents his case for judgment and satisfaction -it behoveth the court and jury to see that the affirmation be proved by sufficient evidence, else the case must be found for the defendant; and so it is also in a criminal case, for, in the eye of the law every man is honest and innocent, unless it be proved legally to the contrary." 16

In this country and in recent times, much emphasis in criminal cases has been put on the presumption of innocence. Always and everywhere great emphasis was placed on the rule that in criminal cases there can be no conviction unless guilt is established with very great clearness-as we say nowadays, beyond reasonable doubt. In civil cases it is enough if the mere balance of probability is with the plaintiff, but in criminal cases there must be a clear, heavy, emphatic preponderance.

Now, what does the presumption of innocence mean? Does it mean anything more than a particular application of that general rule of sense and convenience, running through all the law, that men in general are taken, prima facie-i. e., in the absence of evidence to the contrary, to be good, honest, free from blame, presumed to do their duty in every situation in life; so that no one need go forward, whether in pleading or proof, to show as regards himself or another, that the fact is so, but every one shall have it presumed in his favor? If it does, what is its meaning?

Let us trace the use of this maxim. In recent years, in this country, at the hands of heated counsel and of some judges, it has been given an extraordinary stretch. One may read, for instance, in a late American book on Evidence, the following statement: "The presumption of innocence is not a mere

16 Records of Massachusetts, III., 434-435. 
phrase without meaning; it is in the nature of evidence for the defendant; it is as irresistible as the heavens till overcome; it hovers over the prisoner as a guardian angel throughout the trial; it goes with every part and parcel of the evidence." That "purple patch" is not marked as being quoted from anybody; but in reality, I believe, it was an impassioned utterance of Rufus Choate, one of the most eloquent and successful advocates of his time. ${ }^{18}$ Such a passage as that, gravely woven into the text of a legal treatise may show the extent to which the presumption of innocence has been overdone in our hysterical American fashion of defending accused persons. But let us observe it in its earlier history. In Bracton, say in 1260 , we find it in the most general form-de quolibet homine presumitur quod sit bonus homo donec probetur in contrarium. ${ }^{19}$ In a great and famous continental work on Presumptions by Menochius, ${ }^{20}$ three centuries later, we have the simple phrase: "Illa presumptio qua dicimus quemlibet presumi innocentem," and that is all the emphasis he gives it. In the middle of the next century, the General Court of Massachusetts, in a passage partly quoted before, said, simply and precisely, "It behoveth both court and jury to see that the affirmation be proved by sufficient evidence, else the case must be found for the defendant, and so also it is in a criminal case; for in the eyes of the law every man is honest and innocent unless it be proved legally to the contrary. In criminal prosecutions the presumption is in favor of the defendant, for thus far it is to be hoped of all mankind, that they are not guilty in any such instances, and the penalty enhances the presumption." "21

Very little is said about it before this century, and these quotations fairly illustrate the slight emphasis given it, and the part it plays. In looking through the arguments of Erskine and Curran and other great lawyers famous for their defence of accused persons, and through the charges of the court given to juries-in the last century and the early part of this, we shall find very little, indeed almost nothing, about the presumption of innocence. But a great deal will be found, a very great emphasis is placed, upon the rule that a party must be proved guilty by a very great weight of evidence. That is the important thing.

${ }^{17}$ Bradner, Evidence, 460.

18 Lawson, Pres. Ev. 433 n.

19 Bracton, I93.

${ }^{20} 955$, col. I, I6.

21 Ubi supra. 
And I think it will be found that, in English practice, down to our time, the presumption of innocence-except as a synonym for the general principle incorporated in that total phrase which expresses the rule about a reasonable doubt, namely, that the accused must be proved guilty, and that beyond a reasonable doubt-plays a very small part indeed.

Take, for example, two famous English cases of this century. In Despard's case ${ }^{22}$ the Attorney-General in his opening argument said: "I am, however, gentlemen, ready to admit what no doubt the counsel for the prisoner would be glad to have brought forward to your attention, that the great depravity which is required to conceive and to execute a crime of such extensive mischief, so far from operating to create any prejudice against the prisoner, ought rather to give him a fairer claim to the utmost benefit of that indulgent and salutary principle of: our law, which holds every man to be innocent till he is proved to be guilty; and, therefore, he will unquestionably be entitled to that which I am sure he will experience at your hands, that the charge should be well watched, that the evidence should be well sifted, and that your minds should be most satisfactorily convinced of his guilt, before you think of pronouncing a verdict against him." Serjeant Best (afterwards Chief-Justice Best), for the defence (col. 437) said: "Gentlemen, having made these observations, I am persuaded it will be unnecessary for me to desire you to do all that men can do to divest yourselves of that prejudice which you feel against a man in his situation; to do all that which the Attorney-General has emphatically and distinctly told you to do-that which the law of this country has told you to do-that, without which there can be no liberty existing in this country-that is, to presume him innocent till guilt is established in evidence; for, until his guilt be made out, not merely by vague and unconfirmed stories told by suspicious witnesses, but by that species of evidence which is required by juries in cases of this sort, it is your bounden duty to presume him innocent." And, again, at the end of his argument (col. $45^{8}, 460$ ): "This case is not to be made out by conjecture, you are not to condemn unless all idea of innocence be completely extinguished by the weight of the evidence that has been produced upon the cause. *** Remember the maxim of the Attorney-General, that 'in proportion as the crime is enormous so ought the proof to be clear." "'

At the trial of William Palmer for poisoning in 1856 , the 2228 St. Tr. 345, 363 (I803). 
counsel have nothing to say of the presumption of innocence. And this is what Lord Campbell says in his charge:"23 "Gentlemen, I must begin by conjuring you to banish from your minds all that you may have heard before the prisoner was placed in that dock. * * * I must not only warn you against being influenced by what you have before heard, but I must also warn you not to be infiuenced by anything but by the evidence which has been laid before you with respect to the particular charge for which the prisoner is now arraigned. $* * *$ By the practice in foreign countries it is allowed to raise a probability of the prisoner having committed the crime with which he is charged by proving that he has committed other offences-by showing that he is an immoral man, and that he is not unlikely therefore, to have committed the offence with which he is charged. That is not the case in this country. You must presume that a man is innocent until his guilt is established, and his guilt can only be established by evidence directly criminating him on the charge for which he is tried. *** Unless by the evidence for the prosecution a clear conviction has been brought to your minds of the guilt of the prisoner, it is your duty to acquit him. You are not to convict him on suspicion, even on strong suspicion. There must be a strong conviction in your minds that he is guilty of this offence, and if you have any reasonable doubt you will give him the benefit of that doubt."

That is the simple, intelligible, plain way in which the presumption of innocence is dealt with in important cases in England. The prisoner is, indeed carefully protected, but his bulwark is not found in any emphatic or strained application of the phrase or the fact of a presumption of innocence.

A Scotch case in $1817^{24}$ should now be mentioned. We shall see hereafter the use made of it in Coffin $\%$. U. S. One Andrew McKinley was indicted for administering false oaths. There was a question as to the true interpretation of the oaths, and the counsel for the accused insisted upon his right to have a favorable construction put on them. He said (col. 283): "In all criminal cases everything must be strictly interpreted in favor of the accused and against the prosecutor," and other similar things. The Advocate Depute, replied (col. 334): "A great deal was said about the presumption in favor of the innocence of the panel. This is a common topic of declamation, ${ }^{25}$

23 Palmer's Trial, $x 66$.

24 McKinley's Case, 33 St. Tr. 275.

25 The reader will observe that this is said of Scotland and not of England. 
but I never could understand the presumption of the innocence of a panel. The onus probandi lies on the prosecutor, and he must make out his case, but I see no occasion for a presumption of any sort, but what arises from a want of contrary proof. And I know no such doctrine in any work on the criminal law of Scotland." The defence (col. 438-439) declared that "this was the very first time in a criminal case," that the existence of a presumption of innocence had been denied, and referred to the "very obvious and common-place rule of law that in all trials for crimes there is a presumption in favor of innocence which runs through the whole proceedings and is applied to the indictment, to the proof, to the verdict." In'deciding the question then under discussion in favor of the prosecution, Lord Pitmilly said (col. $5 \times 8$ ) that if anything were doubtful about the construction of the oaths "the presumption must be in favor of innocence. * * We are not to presume guilt because the prosecutor alleges guilt *** and until guilt is established, we must hold the presumption to be in favor of innocence." Lord Justice Clerk said (col. 538), that if the oath were doubtful he was bound "to let the doubt lean in favor of the accused." None of the other judges commented on this subject except the single dissenting judge, Lord Gillies. He said (col. 506) in an emphatic passage that, to be sure, he himself suspected that the oath was as bad as it was contended, "But," he went on, "the presumption in favor of innocence is not to be redargued by mere suspicion. *** The public prosecutor treats this too lightly. He seems to think that the law entertains no such presumption of innocence. I cannot listen to this. I conceive that this presumption is to be found in every code of law which has reason and religion and humanity for a foundation. It is a maxim which ought to be inscribed in indelible characters in the heart of every judge and juryman, and I was happy to hear from Lord Hermand that he is inclined to give full effect to it. ${ }^{26}$ To overturn this there should be legal evidence of guilt, carrying home a degree of conviction short only of certainty."

It will be noticed, as I said, that this is a Scotch case, and Lord Gillies a dissenting judge. The Scotch law is not the common law, and in Scotch courts the Continental refinements about presumptions are far more familiar than in England. The handling of the matter in this case is indeed very simple,

26 All that Lord Hermand is reported as saying on this matter is (col. 499) that "Where there is a possibility of a favorable construction for the panel, it ever will receive effect from me." 
and not at all strained, but the case is not an authority in English law, or at all indicative of any emphasis, even in the Scottish courts, in recognizing the presumption of innocence.

The English conception of the presumption of innocence has been expressed by a writer peculiarly learned in the criminal law, who had devoted much time to the study and exposition of it, and, as a judge, was long engaged in administering it. Fitzjames Stephen, in the second edition of his "General View of the Criminal Law of England," published in 1890 , when the author had been eleven years a judge of the Queen's Bench Division, says (p. 183): "I may mention the general presumption of innocence which, though by no means confined to the criminal law, pervades the whole of its administration. *** [Here he quotes from his "Digest of Evidence" the Article which is given below.] This is otherwise stated by saying that the prisoner is entitled to the benefit of every reasonable doubt. The word 'reasonable' is indefinite, but a rule is not worthless because it is vague. Its real meaning, and I think its practical operation, is that it is an emphatic caution against haste in coming to a conclusion adverse to a prisoner. It may be stated otherwise, but not, I think, more definitely, by saying that before a man is convicted of a crime every supposition not in itself improbable, which is consistent with his innocence ought to be negatived." In his "Digest of Evidence," Article 94, under the title "Presumption of Innocence," he presents as its definition, this: "If the commission of a crime is directly in issue in any proceeding criminal or civil, it must ke proved beyond reasonable doubt. The burden of proving that any person has been guilty of a crime or wrongful act is on the person who asserts it." ${ }_{27}$

This mode of stating or indicating the substance of the presumption of innocence as applied in criminal proceedings, is more or less found in our own decisions. Obviously, it is in a very compact form; and it seems plain that such a statement adds something to the mere presumption of innocence, for that, pure and simple, says nothing as to the quantity of evidence or strength of persuasion needed to convict. But as it is stated above, the rule includes two things: First, the presumption; and second, a supplementary proposition as to the weight of evi-

${ }^{27}$ This article has a second paragraph which runs thus: "The burden of proving that any person has been guilty of a crime or wrongful act is on the person who asserts it, whether the commission of such act is or is not directly in issue in the action." The doctrine here expressed is probably not the law in most parts of this country. 
dence which is required to overcome it; the whole doctrine when drawn out being, first, that a person who is charged with crime must be proved guilty; that, according to the ordinary rule of procedure and of legal reasoning, presumitur pro reo, i.e., neganti, so that the accused stands innocent until he is proved guilty; and, second, that this proof of guilt must displace all reasonable doubt.

As regards the simple, just, unambiguous rule, which, in requiring proof, thus emphasizes the weight of evidence and the strength of persuasion necessary to make it out in a criminal case, this rule, thus appearing to Stephen to embody and to be identified with the presumption of innocence as applied to criminal cases, is a very ancient one. We read in the Corpus Juris, as far back as the fourth century, a direction which is attributed to several Emperors in succession: "Let all accusers understand that in bringing up a matter for judgment it must be supported by fit witnesses, vel apertissimis documentis vel indiciis ad probationem indubitatis et luci clarioribus ${ }^{28}$ This passage was cited for the accused in a Scotch criminal case of piracy in $1705,{ }^{29}$ and scraps of it lingered long in our own books; as when Coke in his Third Institute, 76 , in speaking of treasons, says: "There should be a substantial proof in a cause so criminal where probationes oportent esse luce clariores"; and again, of treason and felony, ${ }^{30}$ that the reason for not allowing counsel to the accused is that, "the testimonies and proofs of offence ought to be so clear and manifest as there can be no defence of it." and still again, he speaks of the rule of law quod in criminalibus probationes debent esse luce clariores." 31

This rule in England was the one constantly pressed; while, as I have said, little or no mention was made in terms of a presumption of innocence. This was the chief rule urged in behalf of accused persons by the great advocates in the last century and later, in such cases as those of Lord George Gordon, Hardy, Horne Tooke and others. MacNally, in his "Treatise on Evidence in Criminal Cases," at the beginning of this century, saying little of a presumption of innocence, remarks: "It may also at this day be considered as a rule of law that if the jury entertain a reasonable doubt they should deliver the prisoner."

${ }_{28}$ Cod. IV. I9, 25.

${ }^{29}$ Captain Green's Case, I4 St. Tr. II99, 245.

so Ih. 29, 137.

$31 \mathrm{Ib} 2 \mathrm{IO}$. 
There is no need to trace it further, for no one doubts that in one form or another this has always continued to be a great and recognized rule. It has, in our inherited system, a peculiarly important function, that of warning our untrained tribunal, the jury, against being misled by suspicion, conjecture and mere appearances. In saying that the accused person shall be proved guilty, it says also that he shall not be presumed guilty; that he shall be convicted only upon legal evidence, not tried upon prejudice; that he shall not be made the victim of the circumstances of suspicion which surround him, the effect of which it is always so diffeult to shake off, circumstances which, if there were no emphatic rule of law upon the subject would be sure to operate heavily against him; the circumstances, e. g., that after an investigation by the grand jury he has been indicted, imprisoned, seated in the prisoner's dock, carried away handcuffed, isolated, watched, made an object of distrust to all that behold him. He shall be convicted, this rule says, not upon any mere presumption, any taking matters for granted on the strength of these circumstances of suspicion; but he shall be proved guilty by legal evidence, and by legal evidence which is peculiarly clear and strong-clear beyond a reasonable doubt. The whole matter is summed up and neatly put by Chief-Justice Shaw in Webster's case:"s2 "The burden of proof is upon the prosecutor. All the presumptions of law independent of evidence are in favor of innocence, and every person is presumed to be innocent until he is proved guilty. If upon such proof there is reasonable doubt remaining, the accused is entitled to the benefit of it by an acquittal." We observe, then, in this form of statement that the general rule of policy and sense, that all persons shall be assumed, in the absence of evidence, to be free from blame, appears in the criminal law, on grounds of fairness and abundant caution, in an emphatic form, as the presumption of innocence, and it is there coupled with a separate special rule as to the weight of evidence necessary to make out guilt.

As to the real nature of the rule about a presumption of innocence, an important intimation is contained in Chief-Justice Shaw's phrase that, "All the presumptions of law independent of evidence are in favor of innocence." That appears to be accurate and exact. The presumption is "independent of evidence," being the same in all cases, and in all operating indiscriminately, in the same way, and with equal force. On what is it founded? On the fact that men in general do not commit crime? On

${ }^{32} 5$ Cush. $295,320$. 
what is the presumption of sanity founded? On the fact that men in general are sane? Perhaps so, as a legislative reason, so to speak, or one of the reasons. But the rule itself is a different thing from the grounds of it, and when we speak of the presumption of innocence or of sanity we are talking of a legal rule of presumption, a legal position, and not of the facts which are the basis of it.

It is important to observe this, because, by a loose habit of speech, the presumption is occasionally said to be, itself, evidence, and juries are told to put it in the scale and weigh it. Greenleaf, in a single phrase, in the first volume of his treatise on Evidence, section thirty-four, a phrase copied occasionally into cases and text-books, has said: "This legal presumption of innocence is to be regarded by the jury in every case as matter of evidence, to the benefit of which the party is entitled." 33 This statement is condemned by the editor of the last edition of Greenleaf's book; and in Taylor on Evidence, the great English handbook, which followed Greenleaf's text closely, this passage is omitted, and always has been omitted. In the latter part of Greenleaf's Evidence, Volume III., which deais specifically with criminal cases, it does not appear. It is denied also by Chamberlayne, the careful editor of the works on Evidence of Best and Taylor.

What can such a statement as this mean-that the presumption is to be regarded as evidence? Is it meant that on grounds of natural presumption or inference, innocence is ordinarily found in criminal cases? As to that, if one would see the true operation of natural inference, and natural presumption in crimi-

${ }^{33}$ Compare the remarks of Clifford, J., in Lilienthal's Tobacco v. U. S., 97 U. S., 237, 267, where an opinion marked by very loose thinking is paraphrasing some unsupported expressions of Wharton on Evidence. It is easy to be misled by the figure of speech about turning the scale. When Greenleaf (Ev. iii. s. 29), in commenting on the difference between criminal and civil cases as to the quantity of evidence required, after saying that in the latter it is enough if the evidence preponderates, adds that "in criminal trials, the party accused is entitled to the benefit of the legal presumption in favor of innocence, which in doubtful cases is always sufficient to turn the scale in his favor;" and that it is a rule of criminal law that the guilt of the accused must be fully proved, and then goes on to give the rule about reasonable doubt-it seems fairly clear that he is not thinking of the presumption of innocence itself, as placed in the scale, but rather of the rule requiring evidence beyond a reasonable doubt, as being placed there; and, of course. that is not so much putting evidence into one scale as saying what evidence shall be put into the other. It is this rule that "turns the scale," and in this way. 
nal cases, and would appreciate how entirely artificial, how purely a matter of policy the whole rule is which bids a jury on the trial to assume innocence, let him turn his attention to the action of courts at other stages than the trial. In State $v$. Mills, 2 Dev. 42 I (I830), as illustrating another point then under discussion, the court (Ruffin, J.) said: "After bill found, a defendant is presumed to be guilty to most, if not to all purposes, except that of a fair and impartial trial before a petit jury. This presumption is so strong, that, in the case of a capital felony the party cannot be let to bail." In Ex parte Ryan, 44 Cal. 555 ( 1872 ), a party indicted for attempting to murder a policeman had been held, in the lower court on $\$ 15,000$ bail. On an application to reduce the bail the court (Wallace, C. J.), retused, saying: "I am bound to assume guilt for the purposes of this proceeding, for certainly I have no means of determining his innocence, to say nothing of the principle of law that, except for the purposes of a fair and impartial trial before a petit jury, the presumption of guilt arises against the prisoner on finding the indictment." In the case of In the matter of Henry Alexander, 59 Mo. 598 (1875), the question was, in a capital case, after repeated trials and disagreements of the jury, whether bail should be allowed. The Constitution of Missouri, it was held, allowed bail, except "when the proof was evident or the presumption great." In allowing it in this case the court (Wagner, J.), said: "The indictment furnishes a strong presumption of guilt. *** Hence, in all such cases, there must be facts and circumstances which counteract or overcome this presumption, before bail will ever be admissible." The same doctrine was held in State v. Madison County Court (Mo., Dec., I896), 37 S. W. Rep. II26, in which the court (Burgess, J.) quotes with approval the language of the Supreme Court of California in People v.Tinker, I9 Cal. 539, that "It [the indictment] creates a presumption of guilt for all purposes except the trial before the petit jury." These cases are the true ones to illustrate the operation of natural presumption and natural inference. Yet, at the trial all such natural probabilities are held off; the board is swept clear of these, and the accused, while kept well guarded, a prisoner, is yet to be treated as if no incriminating fact existed. His record, by a dead lift of legal policy, is now presented as clean and white. Whatever of wrong or guilt is to be inscribed on it must be the result of legal evidence now presented to the jury.

The effect of the presumption of innocence, so far from being that of furnishing to the jury evidence-i. e., probative matter, 
the basis of an inference-is rather the contrary. It takes possession of this fact, innocence, as not now needing evidence, as already established prima facie, and says: "Take that for granted. Let him who denies it, go forward with his evidence." In criminal cases if the jury were not thus called off from the field of natural inference, if they were allowed to range there wherever mere reason and human experience would carry them, the whole purpose of the presumption of innocence would be balked. For of the men who are actually brought up for trial, probably the large majority are guilty. In inquiring lately of a prosecuting officer for the statistics about this, he replied that out of every one hundred persons indicted for crime in his jurisdiction, twenty were tried and acquitted, twenty pleaded guilty, and sixty were tried and convicted. Now the presumption of innocence forbids the consideration of such probabilities as are here suggested and says simply this: "It is the right of this man to be convicted upon legal evidence applicable specifically to him. Start then with the assumption that he is innocent, and adhere to it till he is proved guilty. He is indeed under grave suspicion, and it is your duty to test and fairly to weigh all the evidence against him as well as for him. But he is not to suffer in your minds from these suspicions or this necessity of holding him confined and trying him; he is to be affected by nothing but such evidence as the law allows you to act upon. For the purposes of this trial you must take him to be an innocent man, unless and until the government establishes his guilt."

It may be asked, if then a presumption be not evidence, how can you know when it is overcome? That depends on the nature of the case. It is the office of a presumption, as such, to fix the duty of going on with argument or evidence, on a given question; and is only that. As to how much evidence is to be produced, that is another matter. In criminal cases the rule is fixed that the evidence must negative all reasonable doubt; nothing else will make a case which the defendant need meet. Sometimes the presumption calls only for evidence enough to put the question really into the case, to make it really a question; sometimes for a full prima facie case. But in no case is there a weighing, a comparison of probative quality, as between evidence on one side and a presumption on the other. ${ }^{34}$

s4 See an article on Presumptions and the Law of Evidence, 3 Harv. Law Review, I4I, I65. The author may be allowed, perhaps, to say that a revision of this article will appear later in the year, in the concluding part of his "Preliminary Treatise on Evidence at the Common Law" (Little, Brown \& Co.) 
While then it is true that a presumption may count as evidence, and be a substitute for evidence, in the sense that it will make a prima facie case for him in whose favor it operates, and while it is true that the facts on which a presumption is grounded may count as evidence, the presumption itself; $i$. e., the legal rule, conclusion, or position cannot be evidence. This question was neatly and accurately dealt with by the court in Lisbon v. Lyman, 49 N. H. 553 (r877o). On an issue as to the emancipation of a minor, the jury were instructed "that there was a presumption that children under twenty-one are not emancipated; that the presumption was not conclusive, and the fact might be shown by proof to be otherwise; but that in deciding what the fact was, the jury would take this presumption into account, as one element of evidence, and weigh it in connection with all the testimony." Doe, J., for the court, said: "The burden was on the plaintiff to prove that when the town was divided, the last dwelling place of Volney was in the defendant's territory. The plaintiff claimed, that Volney, though a minor, had, by emancipation, acquired a right to have a home of his own, free from the control of his father. The emancipation of Volney was set up as an affrmative and essential part of the plaintiff's case; and in that view it was necessary for the plaintiff to prove it. Without any evidence, or with evidence equally balanced, on that point, emancipation would not be proved. The burden of proof was on the plaintiff, and this burden was not sustained unless the plaintiff proved it by a preponderance of all the evidence introduced on the subject. But it was not necessary for the plaintiff to produce anything more than the slightest preponderance; or to produce a preponderance of anything but evidence. *** A legal presumptiou is a rule of law-a reasonable principle, or an arbitrary dogma-declared by the court. There may be a difficulty in weighing such a rule of law as evidence of a fact, or in weighing law on one side against fact on the other. And if the weight of a rule of law as evidence of a fact, or as counterbalancing the evidence of a fact, can be comprehended, there are objections to such a use of it. *** A legal presumption is not evidence. *** The presumption against the freedom of minors was not an element of evidence; could not be weighed as evidence, and it does not appear that any use could rightfully be made of it in the case. It was put into the scale with the defendant's evidence, where it would be likely to mis- 
lead the jury, and give the defendant a material advantage to which he was not entitled."

Upon the whole, then, it seems to be true that the presumption of innocence, as applied in criminal cases, is a form of expression which requires to be supplemented by the rule as to the weight of evidence; that it is merely one form of

${ }^{35}$ For a different, and, as I must think, a mistaken exposition of the subject, see Barber's Appeal, 63 Conn. 393, 403, 406 (I893). In a probate appeal involving the question of testamentary capacity, after a verdict against the will, it appeared that the charge of the judge below was objected to by the proponents as "confusing and contradictory." Among other things the judge had said to the jury: "If when the whole matter is before you on the evidence given on both sides, it is left uncertain whether or not the testator was of sound mind, then *** the will should not be sustained. In the course of the trial the balance of evidence may fluctuate from one side to the other, but the burden of proof remains where it was at the outset, upon the advocates of the will, and, unless at the close of the trial the balance is with the advocates of the will, unless the beam of the scale tips down on the side of the advocates of the will, they must fail." The Supreme Court (Fenn, J.) reversed the judgment below, and in the course of a difficult and unsatisfactory exposition of the meaning and application of the term "burden of proof," the opinion says; "The law presumes every person to be so [of sound mind] until the contrary is shown, and this presumption is of probative force in favor of the proponents of the will. *** In short *** on the whole case the question would be whether the evidence of the contestants sufficiently preponderated over the rebutting and special evidence of the proponents, including the evidence of the attesting witnesses, to overcome'the presumption of sanity which constituted the proponent's prima facie case. In other words, leaving the presumption of sanity out of the case, was there more evidence of insanity than of sanity? So that, putting it again into the case there would still be as much. Then and then only would the scales of justice, to which the court below in the case before us referred, be so adjusted, according to law, that it would be correct to say ' unless at the close of the trial the balance is with the advocates of the will they must fail; it is not sufficient that the scales stand evenly balanced." 'The opinion does not give its reasons for the statement that the presumption has a probative quality, and can be "weighed in the scale," and the case does not necessarily involve the point above discussed; so that it is quite possible that the above exposition does not carry with it the authority of all the judges of the court. For the true basis and operation of this presumption see Davis $v$. U.S., I6o U.S. 469, 486 (I895): "If that presumption [of sanity] were not indulged the government would always be under the necessity of adducing affirmative evidence of the sanity of an accused. But a requirement of that character would seriously delay and embarrass the enforcement of the laws against crime, and in most cases be unnecessary. Consequently the law presumes that everyone charged with crime is sane, and thus supplies in the first instance the required proof of capacity to commit crime. It authorizes the jury to assume at the outset that the accused is criminally responsible for his acts." Harlan, J., for the Court. 
phrase for what is included in the statement that an accused person is not to be prejudiced at his trial by having been charged with crime and held in custody, or by any mere suspicions, however grave; but is only to be held guilty when the government has established his guilt by legal evidence and beyond all reasonable doubt; that the presumption of innocence is often used as synonymous with this whole twofold rule, thus drawn out; that it is a convenient and familiar phrase, and probably a useful one, when carefully explained; but that it has not played any conspicuous part in the development of our criminal law except as expressed in the fuller statement given above. It may be added that the phrase presumption of innocence if usea to a jury, peculiarly needs to be carefully explained, because of the very great ambiguity connected with the terms "presumption," "burden of proof" and "evidence," and the way in which these abused expressions reflect their own ambiguities upon each other.

Let me return now to the case of Coffin $v$. U. S. ${ }^{36}$ It will be necessary to consider it in some detail. It came up from the Circuit Court of the United States for Indiana, and was a proceeding against officials of a National Bank who were convicted below of wilfully misapplying funds of the bank, and of other related offenses. A great number of exceptions were taken to the charge given by the court to the jury. All but two of these were overruled. The principal exception was against the refusal of the judge to charge as he was requested on the subject of the presumption of innocence. ${ }^{37} \mathrm{He}$ had been asked to charge that, "the law presumes that persons charged with crime are innocent until they are proved by competent evidence to be guilty. To the benefit of this presumption the defendants are all entitled, and this presumption stands as their sufficient protection unless it has been removed by evidence proving their guilt beyond a reasonable doubt." The judge refused to give this charge, but instructed the jury that they could not find the defendants guilty unless satisfied of their guilt beyond a reasonable doubt, and he said: "If you can reconcile the evidence with any reasonable hypothesis consistent with the defendant's innocence, it is your duty to do so. In that case find defendant not guilty. And if, after weighing all the proofs, and looking only to the

${ }^{36} 156$ U. S. 432.

37 The action of the trial Judge is described in the opinion of the upper court thus: "Whilst the court refused to instruct as to the presumption of innocence, it instructed fully as to reasonable doubt." This statement is not quite exact, as will be indicated later. 
proofs, you impartially and honestly entertain the belief that the defendant may be innocent of the offences charged against him, he is entitled to the benefit of that doubt, and you should acquit him." In various forms the judge went on to explain what "a reasonable doubt" is, and to make very clear the duty of the jury as to the weight of evidence which they were bound to require before they could find guilt.

The Supreme Court held that there was error in refusing the charge which was desired on the presumption of innocence; and, while recognizing that no particular form of words was necessary, in dealing with this presumption, they held that the error was not made good by anything found in the rest of the charge. The opinion of the court was given by Mr. Justice White, and was not accompanied by any expression of dissent. It declares that the principle that there is a presumption of innocence is "axiomatic and elementary, and its enforcement lies at the foundation of the administration of our criminal law." Many citations are given to show that there is a presumption of innocence. The doctrine that guilt can only be found by the clearest evidence is quoted from various writers, and this principle is referred to as being, in the language of the court, one of the "results of this maxim" of the presumption of innocence, but no reason is given for this view other than what will be stated hereafter. The language of Lord Gillies, the dissenting judge in the Scotch case already referred to, McKinley's case, is cited at length, as showing, in the phrase of the opinion, "how fully the presumption of innocence had been evolved as a principle and applied at common law'; but it is not remarked that this is a dissentirg opinion, and that the case is a Scotch case, and not one at common law. The opinion then goes on to inquire whether the charge did substantially embody a statement of the presumption of innocence. It is declared that the authorities upon what is a sufficient statement of this presump. tion are "few and unsatisfactory." Referring to cases in Texas, Indiana, Ohio. Alabama and California, on one side and the other of the question, to an anonymous article in the Criminal Law Magazine, and to Stephen's statement of the presumption of innocence, and the remarks of Mr. Chamberlayne, the editor of Best, the opinion goes on to say that it is necessary to consider "the distinction between the presumption of innocence and reasonable doubt, as if it were an original question." The question is then put as being "whether the two are equivalents of each other?" and it is proposed to "ascertain with accuracy in 
what each consists." It may be remarked, at this point, that this form of putting the question, imputes a very fatuous confusion of ideas to those who hold that the rule requiring proof of guilt beyond a reasonable doubt embodies in it all that the presumption of innocence really means. They would hardiy agree that they are arguing that the presumption of innocence and reasonable doubt are "equivalents of each other"; or that the exploit of the opinion as it is described in a later case ${ }^{88}$ in saying, "The court drew a distinction between the presumption of innocence as one of the instruments of proof, contributing to bring about that state of case from which reasonable doubt arises, and a condition of mind called reasonable doubt produced by the evidence,"-that this feat was either one that required much pains to accomplish or one that particularly concerned their own contention.

Having thus started on this interesting and important inquiry the opinion proceeds: "The presumption of innocence is a conclusion drawn by the law in favor of the citizen, by virtue whereof when brought to trial on a criminal charge he must be acquitted unless he is proven to be guilty. In other words, this presumption is an instrument of proof created by the law in favor of one accused whereby his innocence is established until sufficient evidence is introduced to overcome the proof which the law has created. This presumption, on the one hand, supplemented by any other evidence he may adduce, and the evidence against him on the other, constitute the elements from which the legal conclusion of his guilt or innocence is to be drawn." The court then quotes the passage from Greenleaf on Evidence, ${ }^{39}$ upon which I have commented; a passage from Wills on Circumstantial Evidence, stating that there is such a presumption and that it prevails "until destroyed by such an overpowering amount of legal evidence of guilt as is calculated to produce the opposite belief"; another from Best on Presumptions, simply saying that it is presumptio juris; another from an anonymous article in the Criminal Law Magazine, ${ }^{40}$ stating that the presumption is "in the nature of evidence in his favor. and a knowledge of it should be communicated to the jury," etc. The opinion then goes on, "The fact that the presumption of innocence is recognized as a presumption of law, and is char-

${ }^{38}$ Cochran $v$. U. S., I57 U. S.. 286, 299.

${ }^{29}$ Grlf. Ev. I. S. 34 .

10 Which appears to have been an advance chapter of Thompson on Trials. The passage is found in that work, s. $246 \mathrm{r}$. 
acterized by the civilians as presumptio juris, demonstrates that it is evidence in favor of the accused; for in all systems of law legal presumptions are treated as evidence giving rise to resulting proof to the full extent of their legal efficacy. Concluding then that the presumption of innocence is evidence in favor of the accused, introduced by the law in his behalf, let us consider what is reasonable doubt." We are then told that reasonable doubt is "the condition of mind produced by the proof resulting from the evidence in the cause. It is the result of proof, not the proof itself; whereas the presumption of innocence is one of the instruments of proof going to bring about the proof from which reasonable doubt arises; thus one is a cause, the other an effect. To say that the one is the equivalent of the other is therefore to say that legal evidence can be excluded from the jury, and that such exclusion may be cured by instructing them correctly in regard to the method by which they are required to reach their conclusion upon the proof actually before them. In other words, that the exclusion of an important element of proof can be justified by correctly instructing as to the proof admitted." Farther on, the opinion says: "It is clear that the failure to instruct them [the jury] in regard to what that is [the presumption of innocence], excluded from their minds a portion of the proof created by the law, and which they were bound to consider." And it is added that the judge below in limiting the attention of the jury " 'to the proofs and the proofs only' confined them to those matters which were admitted to their consideration by the court, and among these elements of proof the court expressly refused to include the presumption of innocence to which the accused was entitled, and which the court was bound to extend him."

The following remarks are also thrown in near the end of the discussion: "The evolution of the principle of the presumption of innocence, and its resultant, the doctrine of reasonable doubt, makes more apparent the correctness of these views, and indicates the necessity of enforcing the one in order that the other may continue to exist. While Rome and the Mediævalists taught that wherever doubt existed in a criminal case acquittal must follow, the expounders of the common law in their devotion to human liberty and individual rights traced this doctrine of doubt to its true origin, the presumption of innocence, and rested it upon this enduring basis." It would be instructive to know the ground for this statement as to "the expounders of the common law," and the establishing 
of this "enduring basis." Unless the phrase refers to an occasional lonse dictum of a law writer or judge in this country, or to an occasional ill-considered judicial opinion here, I know of no ground for these remarks.

Such was the decision, in Coffin $v$. U. S., so far as relates to the point now under consideration, and such was the general course of the exposition. It proceeds, in a word, on the ground that the lower court refused to recognize the presumption of innocence, and thus kept from the jury a piece of evidence in behalf of the accused to which he was entitled. The immediate result of the decision was that it helped to delay the punishment of persons well deserving it, as appeared when the case came back again after another trial, and all of "very numerous grounds of error" urged by these defendants were overruled." It is interesting to observe that, at the new trial, the charge, so far as quoted, dealt with the matters now under consideration in this form (p. 68I): "The burden of proving Haughey and the defendants guilty as charged rests upon the government, and the burden does not shift from it. Haughey and the defendants are presumed to be innocent until their guilt in manner and form * * * is proved beyond a reasonable doubt. To justify you in returning a verdict of guilty, the evidence should be of such a character as to overcome this presumption of innocence and to satisfy each one of you of the guilt of Haughey and the defendants as charged, to the exclusion of every reasonable doubt." This instruction seems to have raised no question. Except as leaving to the jury without explanation two phrases full of ambiguity, namely, "presumption of innocence" and "evidence * * * to overcome" it, it seems not to differ materially from the former charge. Can it reasonably be supposed that on such a charge anybody would imagine the presumption to be a piece of evidence, to be placed in the scales and weighed against other evidence? Such a charge is only in form an acceptance of the exposition in the former opinion of the Supreme Court; it is mere lip service. ${ }^{42}$

That opinion, however, has had an effect outside of the particular case. Its somewhat wider range than common of reference and allusion, has caused the imputing to it of an amount of learning and careful research to which, when scrutinized, it can lay no claim; and, to be quite just, it does not, in fact, lay claim to it. But it does lay claim to exactness of discrimination, to a

11 Coffin v. U. S., I62 U. S. 664 (May, I8g6).

${ }^{43}$ See also Agnew $v$. U. S., I7 S. C. R. 234, 24 I (January, 1897). 
searching and fundamental examination of the nature of the questions involved, and to the character of a leading and, in a degree, a final discussion of a peculiarly vexed and difficult subject. This claim must be disputed. What has been said in the earlier pages of this paper will serve to show grounds for denying the truth of the chief historical suggestions of the opinion, and the validity of some of its fundamental conceptions. Instead of settling anything outside of the particular controversy, it leaves matters worse off than before. Its work of mischief may be seen in the use of it in such later cases as Cochran $v$. U. S. ${ }^{43}$ U. S. v. Davis'"1 Agnew v. U. S. ${ }^{45}$ (I ảo not now speak of the actual point decided in either of these cases), and No. Ca. v. Gosnell..$^{46}$ The difficulty with the case is not with the actual decision-namely, that on the point in question a new trial was granted; that could easily be agreed to, without any serious difference as to the principal matters. The trouble is with the exposition and the reasons. The absence, therefore, of dissent in this case may have very little significance."

It may readily be admitted, as the event shows, that it would have been practically wiser on the part of the judge below to have given the charge as requested and to have accompanied it

${ }^{43} 157$ U. S. 286 (March 25, I895).

14 I60 U. S. 469 .

15 I7 S. C. R. 234.

${ }^{16} 74$ Fed. Rep. 734 (W. D. No. Ca., June, 1896).

47 That the exposition and the reasoning in Coffin $v$. U. S., I56 U. S. 432, count for little in the mind of the court, may be seen in Allen $v$. U. S., I64 U. S. 492,500 (Dec. I896). Error was assigned in a refusal to charge that "where there is a probability of innocence, there is a reasonable doubt of guilt." In overruling the exception, the court (Brown, J.) after remarking that in the Coffin case a refusal to charge on the presumption of innocence was held not to be met by a charge that a conviction could not be had unless guilt were shown beyond a reasonable doubt, added: "In the case under consideration, however, the court had already charged the jury that they could not find the defendant guilty unless they were satisfied from the testimony that the crime was established beyond a reasonable doubt; that this meant: 'First, that a party starts into a trial, though accused by the grand jury with the crime of murder, or any other crime, with the presumption of innocence in his favor. That stays with him until it is driven out of the case by the testimony. It is driven out of the case when the evidence shows beyond a reasonable doubt that the crime as charged has been committed, or that a crime has been committed. Whenever the proof shows beyond a reasonable doubt the existence of a crime, then the presumption of innocence disappears from the case. That exists up to the time that it is driven out in that way by proof to that extent.' The court having thus charged upon the subject of the presumption of innocence could not be required to repeat the charge in a separate instruction at the request of the defendant." Compare Agnew v. U. S., ubi supra. 
with such explanations as would clear away ambiguity and would prevent the jury from misapplying the statements. And, farther than that, it may be true, as a general proposition, that the right should be maintained to have the presumption of innocence, specifically and by name, drawn to the attention of the jury. If so, it should also be required that it be definitely and accurately explained, so that it be not misused as if in itself it constituted a piece of probative matter to be weighed against other evidence; and again, so that it be not used in a way to prevent the jury from allowing all evidence against the accused to have its full natural effect, all through the case, as it is put in. Certainly such a specific declaration and explanation as to the presumption of innocence would draw pointed attention to those dangers of injury to the accused from mere suspicion, prejudice or distrust, and to those other grounds of policy on which it rests, which make these judicial warnings so important.

Now what, exactly, was it that the judge below said on this subject? He said something which, although quoted, is not commented upon, or, as it would seem, duly appreciated by the court, viz: "If, therefore, you can reconcile the evidence with any reasonable hypothesis consistent with the defendants' innocence, it is your duty to do so, and in that case find the defendants not guilty. And if, after weighing all the proofs, and looking only to the proofs, you impartially and honestly entertain the belief that the defendants may be innocent of the offense charged against them, they are entitled to the benefit of that doubt, and you should acquit them." This language required the jury, in considering the evidence, to put upon it the construction most favorable to the defendants' innocence. In effect it said to the jury. "So long and so far as you reasonably can, hold them innocent, assume them innocent, or, if you please, presume them innocent, for these forms of phrase mean the same thing. Let nothing but legal evidence count against them, look to the proofs and the proofs only, and let not the evidence or any amount of evidence count against them, so long as you can continue as reasonable men to think them innocent."

When the judge below had said that, in addition to further elaborate and confessedly adequate instructions as to the rule which requires a weight of evidence beyond reasonable doubt, I think that it cannot truly be said, as the opinion does say, that "the court refused to instruct as to the presumption of innocence"; and, again, that "among these elements of proof the court expressly refused to include the presumption of inno- 
cence." What the judge below did was, in reality, to refuse to instruct in the particular form requested; and that sort of refusal is not necessarily fatal; for, as the court in the Coffin case justly says, "It is well settled that there is no error in refusing to charge precisely as requested, provided the instruction actually given fairly covers and includes the instruction asked." The whole question is, then, whether the instruction below fairly covers the instruction asked. The instruction asked was this: "The law presumes that persons charged with crimes are innocent until they are proven by competent evidence to be guilty. To the benefit of this presumption the defendants are all entitled, and this presumption stands as their sufficient protection, unless it has been removed by evidence proving their guilt beyond a reasonable doubt." I think that this charge was, in effect, given when the jury were told that they were to reconcile the evidence with the supposition of the defendant's innocence if it was reasonably possible; to consider nothing but the evidence and only to find the defendants guilty when the evidence proved it beyond a reasonable doubt.

It will be noticed that the charge requested did not ask for any explanation of the presumption of innocence, nor did the charge given make any explanation of it. As the request for a charge did not say that the presumption of innocence was in itself evidence, so the charge given did not deny that it was evidence. Why the jury should presume innocence was not stated in the request for a charge, and in the charge as actually given it was not stated why the jury should construe the evidence favorably to the accused so long as it was reasonably possible to do so. It was not necessary to do it, in either case, for in both cases it was a rule that was being laid down to the jury, and the grounds of the rule were not necessarily to be stated. In so far as evidence, in any proper sense of the word, was concerned, no question was made about it, in the talk about the presumption. If it be thought true that the fact that men in general are innocent is the evidential ground for the rule mentioned in the request, or in the charge, it was nothing to the purpose to go into that; for it is merely the legislative reason for laying down such a rule. In so far as the facts on which the rule rests were themselves to be regarded as evidence or a basis for inference in the case, the request draws no attention to them, and the mere omission to charge on them is no legitimate ground of exception-according to a familiar rule on that subject. Moreover, in so far as the fact that men in general are 
innocent is a ground of inference for the jury it is one to be taken notice of by court, counsel and jury without proof, and without anybody's moving them thereto. Certainly there was no refusal of any request to call the attention of the jury to the fact that men in general are innocent; the refusal was one to charge on the presumption of innocence in the form above stated, and that form offered no suggestion whatever as to what the true import of the phrase is. The accused then had no cause of complaint that any request of his counsel was refused.

But now we come to the kernel of the matter, the exposition in the opinion of the meaning of that phrase. Let us look at that. It is said that the presumption of innocence is a conclusion drawn by the law by virtue of which, on a trial, the accused must be acquitted unless proved guilty. This, it will be observed, states the presumption as being a legal "conclusion" requiring exactly what was fully set forth by the trial judge. Then we are told that the presumption is an instrument of proof created by law in favor of the accused whereby his innocence is established until sufficient evidence is introduced to overcome the proof which the law has created. Here the presumption becomes an instrument of proof establishing innocence, and is itself proof, created by the law. This presumption, it is said again, supplemented by any other evidence the accused may produce, on the one hand, and the evidence against him on the other, constitute the elements from which the legal conclusion of guilt or innocence is to be drawn. Here the presumption, our "conclusion drawn by the law," our "instrument of proof," our "proof created by law," becomes evidence; $i$ e., probative matter, to be added to the evidence of the accused, and balanced against the evidence of the government. How the presumption can be weighed and estimated as evidence we are not told.

After some quotations the opinion then says that the fact that the presumption of innocence is a presumptio juris, demonstrates that it is evidence in favor of the accused; for, it is added, in all systems of law, legal presumptions are treated as evidence giving rise to resulting proof, to the full extent of their legal efficacy. No authority is given for that statement, and no explanation of what it means; but it is added, "Concluding then that the presumption of innocence is evidence in favor of the accused, introduced by the law in his behalf," etc., etc.; and then later, it "is one of the instruments of proof, going to bring about the proof from which reasonable doubt arises." 
Again, the exclusion of it is called excluding "legal evidence," excluding "an important element of proof," excluding "a portion of the proof created by law."

To sum it up, the substance of all this is, as I have said before, that the presumption of innocence is a piece of evidence, a part of the proof-i.e., a thing to be weighed as having probative quality. And the grounds for saying it are: (I) The authority of the phrase in Greenleaf's Evidence, to which I have referred; (2) A similar phrase in an article in the Criminal Law Magazine, that it "is in the nature of evidence"; to which are added (3) a statement in another text-book (Wills' Circumstantial Evidence) that the presumption must prevail till destroyed by such an overpowering amount of legal evidence of guilt as is calculated to produce the opposite belief; and (4) a statement in Best on Presumptions that it is presumptio juris. This is the authority, and it is slight indeed. And the opinion adds a strange, unsupported assertion that the recognition of the presumption of innocence as a presumption of law (presumptio juris) demonstrates it to be evidence, and that in all systems of law legal presumptions of law are treated as evidence. It is easy to make such an assertion and to leave the matter there. But as one who has long and attentively studied the subject of presumptions, I can only say that I know of nothing to support it in any sense which tends to sustain the reasoning of the opinion.

What appears to be true may be stated thus:

I. A presumption operates to relieve the party in whose favor it works from going forward in argument or evidence.

2. It serves therefore the purposes of a prima facic case, and in that sense it is, temporarily, the substitute or equivalent for evidence.

3. It serves this purpose until the adversary has gone forward with his evidence. How much evidence shall be required from the adversary to meet the presumption, or, as it is variously expressed, to overcome it or destroy it, is determined by no fixed rule. It may be merely enough to make it reasonable to require the other side to answer; it may be enough to make out a full prima facie case, and it may be a great weight of evidence, excluding all reasonable doubt.

4. A mere presumption involves no rule as to the weight of evidence necessary to meet it. When a presumption is called a strong one, like the presumption of legitimacy, it means that it is accompanied by another rule relating to the weight of evidence to be brought in by him against whom it operates. 
5. A presumption itself contributes no evidence, and has no probative quality. It is sometimes said that the presumption will tip the scale when the evidence is balanced. But, in truth, nothing tips the scale but evidence, and a presumptionbeing a legal rule or a legal conclusion-is not evidence. It may represent and spring from certain evidential facts; and these facts may be put in the scale. But that is not putting in the presumption itself. A presumption may be called "an instrument of proof," in the sense that it determines from whom the evidence shall come, and it may be called something "in the nature of evidence," for the same reason; or it may be called a substitute for "evidence, and even "evidence"-in the sense that it counts at the outset, for evidence enough to make a prima facie case. But the moment these conceptions give way to the perfectly distinct notion of evidence proper-i. e., probative matter, which may be a basis of inference, something capable of being weighed in the scales of reason and compared and estimated with other matter of the probative sort-so that we get to treating the presumption of innocence or any other presumption, as being evidence in this its true sense, then we have wandered into the region of shadows and phantoms.

James Bradley Thayer 